Peuples indigènes et environnement

\title{
The Desert Away from Home: Amos Oz's Memoir, Levinasian Ethics, and Binaries of Pain in the Israeli-Palestinian Conflict
}

\section{Orit Rabkin}

\section{(2) OpenEdition \\ Journals}

Electronic version

URL: http://journals.openedition.org/elohi/939

DOI: 10.4000/elohi.939

ISSN: 2268-5243

\section{Publisher}

Presses universitaires de Bordeaux

\section{Printed version}

Date of publication: 1 July 2015

ISBN: 979-10-300-0130-3

ISSN: 2431-8175

\section{Electronic reference}

Orit Rabkin, «The Desert Away from Home: Amos Oz's Memoir, Levinasian Ethics, and Binaries of Pain in the Israeli-Palestinian Conflict », ELOHI [Online], 8| 2015, Online since 01 July 2015, connection on 01 May 2019. URL : http://journals.openedition.org/elohi/939; DOI : 10.4000/elohi.939 


\section{The Desert Away from Home: Amos Oz's Memoir, Levinasian Ethics, and Binaries of Pain in the Israeli-Palestinian Conflict}

\section{ORIT RABKIN \\ Ben Gurion University of the Negev, Beer-Sheva (Israel)}

Writing a memoir describing the early days of the Zionist state hardly seems exceptional, yet Amos Oz's A Tale of Love and Darkness (2004) achieves exceptionality. $\mathrm{Oz}$ achieves what most Israelis, including myself, struggle with. On the one hand, he shares with his readers his Jewish family's persecution in the Eastern European Diaspora followed by an insider's, sympathetic description of the Zionist project of rebuilding the ancient homeland. On the other hand, he deeply feels the pain of those others whom, as an Israeli Jew, I can see are still reeling from our return. Oz creates a narrative space that acknowledges Jewish presence without needing to simultaneously preclude Arab claims (all the while focusing on his family and his people). The narrative space relies on the sounds echoing in the desert: it echoes with biblical, philosophical, and ancient moral as well as contemporary conversations. Oz creates a world that refuses to succumb to binaries that perpetuate war. He refuses the instinct ingrained in so many Israeli Jews, the instinct to concentrate on our own community's pain to the point of blinding ourselves to the pain of our neighbors. In so doing, he calls on ancient Jewish tradition and Jewish philosophy that reiterates responsibility towards others as a central tenant of ethical living.

Though most of the population is Jewish, Israel's population is diverse. About twenty four percent of Israel's population are non-Jews: there are also Christian Arabs, Muslims, Druiz (mainly in the north), Bedouins (mainly in the south), and other smaller minorities ${ }^{1}$. All of them call Israel home but more

1 For updated information on the demography of Israel see the Jewish Virtual Library. The Jewish Virtual Library is one of the largest Jewish historical and cultural, non profit 
importantly, they all consider Israel in particular and the Middle East generally, their spiritual and religious home. Most of the Jewish population are recent immigrants heading the call of Biblical stories telling them that their political and spiritual center is Jerusalem. Though there has been continual Jewish presence in Israel, Zionism came from Europe mainly, where Jewish people sought reprieve from constant anti-Semitism. They longed for a place they originally belong to. If Europeans spent centuries pushing the Jewish population to the fringes because they did not belong, then surely there was a space on Earth from which Jews came and to which they can return.

Massive emigration out of Europe began in the aftermath of a wave of particularly brutal attacks or Pogroms on the Jewish population (mainly in Russia). While there were many Jews who left Europe for the United States and other locations around the globe, others deeply felt a pull to the landscape of the bible 2 . The modern political conflict, in other words, stems also from competing origin stories inside a very small physical space. It can be argued, therefore, that the narrative space is all the more crucial to negotiate ${ }^{3}$. If Zionism, as least its political roots, delve into Joshua-like conquering of the land, Oz's text offers an alternative wherein Zionism is capable of inhabiting more than one story of being in this space. Oz takes advantage of the desert space transforming it into a narrative where different groups contend for political claims based on indigenous claims. Who gets to talk about their past when the same environment, same physical landscape is claimed by different origin stories? This is where the narrative environment can enter the conversation to help create overlapping spaces or at least spaces where conciliatory-political considerations can and do exist.

This essay will explore the philosophical system residing deep between the lines of Oz's memoir to expose the ways Oz rewrites what I will call the "binary of pain." The crux of his tactic lies in his implicit reminder to his readers that as

databases available. For this entry, the editors collected the information from Israel's Ministry for Foreign Affairs.

2 For more information of Russian Pogroms see the Modern Jewish History: Pogroms page of the Jewish Virtual Library. It draws its entry from the Encyclopedia Judaica and offers a list of further bibliographical information. For more information about European Jewry, more focused on Zionism's historical roll, see The Zionist Idea, A Historical Analysis and Reader. Also : A History of Zionism : From the French Revolution to the Establishment of the State of Israel by Walter Laqueur.

3 Irving Howe's World of Our Fathers (1976) remains one of the most comprehensive and most quoted historical review of Jewish-American history at the end of the nineteenth century. It focuses on the United States to show both the violence Jews faced back in Russia and their challenges upon immigrating in such large numbers into the United States. 
Jews, we have a responsibility towards others. A close reading of a short pivotal passage in which $\mathrm{Oz}$, in the present tense, describes an encounter in the desert with a Bedouin woman, offers a way of talking about Israeli Jewish responsibility toward others. This moment in Tale of Love and Darkness acts to reveal the philosophical system at work in this memoir and in responsible Judaism itself; during his description of an early-morning desert encounter at the edge of his town, Zionism is transformed. From a Joshua-like conquest story, the desert encounter conjures the desert's homeless, nomadic promise, and most importantly, the desert's existence as the place where Jewish responsibility toward the ger, the stranger, and the orphan originated. The term "binary of pain" acts here to highlight Zionism's potential, a potential inherent in its Jewish roots for acting-out an encounter with the others such as with Palestinians rather than enacting further the language of war. In place of the Israeli-Palestinian binary stressing the fissure, rests a Levinasian-like encounter where recognition of the "whole humanity" of the other becomes possible". If nothing else, such acknowledgment posits a shared anguish; more than anything else, pain inhabits Oz's writing in Tale of Love and Darkness.

Readers familiar with earlier works of $\mathrm{Oz}$ have come to expect a kind of story that challenges rather than accepts mainstream Israeli narratives. As Ranen Omer-Sherman explains in Israeli in Exile: Jewish Writing and the Desert (2006), "Oz exemplifies a generation that consciously distances itself from an earlier generation's solidarity with the prevailing public line" (61). Indeed, $\mathrm{Oz}$ is one of the most widely read and best known writers inside of Israel. In addition, his books have been translated into many languages. Moreover, he has become a public intellectual, offering his political commentary in countless television, radio interviews, and newspaper articles ${ }^{5}$. A Tale of Love and Darkness offers an exciting chance to read the memoir of a figure who has exerted both literary

4 Emmanuel Levinas (1906-1995), though generally less known than his teacher, Heidegger, has nevertheless occupied a central role in twentieth century philosophy. $\mathrm{He}$ broke from Heidegger both on political grounds (Heidegger joined the Nazi party) and on philosophical ground (as explained here). He was born Jewish and studied Jewish philosophy, religion, and thought, infusing into his conversation with Christian philosophy these Jewish ideas. He also studied with the Edmond Husserl. For more about his biography and his philosophy: Is it Righteous to Be?: Interviews with Emmanuel Lévinas (2001) edited by Jill Robbins. I will use specific interviews from this edition in this article. For more biographical information see introduction to Emmanuel Levinas, Basic Philosophical Writings (see works cited).

5 For a concise, comprehensive, biographical profile of Oz, 'The Spirit Level: Amos Oz Writes the History of Israel' published in The New Yorker (November 8, 2008), issue by David Remnick. 
and political influence for about forty years in Israel. He takes his own life story, and that of his family, to make a public statement. In other words, the memoir is more than a literary moment of private recollection, it acts also as a public document invoking an insistence on the possibilities within the Jewish political landscape. A Tale of Love and Darkness engages the ethos of peace and land. The short passage I offer here points to a possibility of encountering the "enemy" on shared home ground, as it were. The passage highlights that government-sanctioned grand-strategies - strategies of war - almost necessarily result in violent solutions. Levinasian ethics - offering a tactics of encounter rather than the strategic binaries of war - operate in Oz's memoir, opening a space for smaller gestures that beget resolutions. Instead of grand gestures of peace-making efforts born of enemy-binaries, Oz's memoir can be read as arguing for a different position; he imagines a step that might open the conversation to aspects of justice on contested indigenous grounds.

In order to shift the conversation, as $\mathrm{Oz}$ does, from one which assumes that a state of war exists - a situation which necessitates strategic "solutions" - to a conversation which acknowledges binaries of pain, binaries which necessitate an environment of justice, this essay will rely on the work of Emmanuel Levinas as well as will argue that dissenting voices to the master narratives existed consistently inside Zionist politics. Levinas' work on issues of justice mainly through his assertion that first and foremost, one's own existence is predicated on encounters with others, have recently received growing attention in Jewish Studies as well as elsewhere ${ }^{6}$. Second, I will use Ranen Omer-Sherman's Israel in Exile: Jewish Writing and the Desert, which focuses on the desert in Jewish literature and which also utilizes Levinasian ethics. In his book, he works to recover a largely overlooked tradition, a three-generational resistance to the Zionist master-narrative. From the earliest days of the Zionist state and the Zionist pre-state, the master-narrative was challenged ${ }^{7}$. Omer-Sherman places $\mathrm{Oz}$, who was a young boy during the Independence war, as part of second

6 Jacques Derrida famously embraced him in what has come to be known as his "later" work on ethics. Derrida wrote Adieu to Emmanuel Levinas in 1997 (the original French publication date).

7 Shulamit Hareven, a member of the first generation fought in Israel's Independence war. She helped establish the Israel Defense Force (IDF) and continued to write all her life. She remained an active proponent of peace while arguing for justice. She arrived in Palestine in 1940, having survived the war. She was a Zionist, and also a longtime member of the Shalom Achshave, or Peace Now movement, dedicated to "the right of Israel to live within secure borders and the right of our neighbors to do the same" (peace now). Omer-Sherman was born in the U.S. The generation of '73 is a fourth generation. For more information about Hareven, see the Jewish Virtual Library. 
generation of resistant voices. In turn, I offer Omer-Sherman as the third generation, an additional voice that builds on their conversation, continuing it from the United States. I include him in the conversation also because he spent years in Israel, served in the Israeli military (known as the Israel Defense Force or IDF), and helped establish a Kibbutz before returning to the United States. The fact that he lived in the desert, felt its power and returned to the States to write about its open spaces, establishes a resonance to that only having spent time in the ancient land can. The desert offers a kind of aesthetic and barrenness to a Westerner and "humbles one in numerous ways, reducing the intellectual to unprecedented awareness," explains Omer-Sherman (xiii).

Stepping out from his town into the desert "every morning" and discovering the "full depths of the desert silence" means quite literally for Oz stepping into a realm that skirts Western rationalism, a place where the local tactics of encounter supersede strategy. In this way, he can step outside of the Zionist rationalism that Levinas complains about $(\mathrm{Oz} 304)$.

\section{Classic Zionism, Levinas, warfare, and binaries of pain}

In "Difficult Freedom" Levinas offers the following criticism of Zionism and modern secular Judaism in general: "Judaism emerges, perhaps, more aware of what it has received but less and less sure of its own truth" (Levinas 1998: 251). Levinas complains that a scientific, Enlightenment-driven understanding of Judaism divests it of its spirituality ${ }^{8}$. More crucially, the reduction of "the miracle of the Revelation or the national genius to a series of influences" (Levinas 1998: 251) denies significance to that same spirituality. Levinas complains specifically about the fruits of Theodore Herzl's secularist, rationalist dogma (shared by other Zionist patriarch discussed further on). Contemporary Israeli thought the same rational thought at the base of classic Zionism that organizes itself in the grand "strategies" of the master narrative of reason - divorced itself, Lev-

8 In 1923 Levinas studied philosophy in France. He joined the French army in 1939 as an interpreter of Russian and German. Early on he was captured and because he was a soldier, was held as a prisoner of war and, though certainly having a hard time under the Germans, he was spared the concentration camps. His wife and daughter were spared only through the efforts of his close friend Maurice Blanchot and others. He studied under Martin Heidegger. Although he also relied heavily on Jewish Talmudic ethical teachings he often remarked that he viewed himself primarily as a Western philosopher. Those of us who draw on him within Jewish Studies tend to claim him as our own, however. He was, after all, the first to admit that his Jewish background and his study of the Talmud influenced greatly his ethical, philosophical work. See introduction to Basic Philosophical Writings and The Levinas Reader (works cited) 
inas argues, from its ethical and spiritual basis, which it received in the desert prior to returning into the homeland.

The Zionist master-narrative relies for eminent, practical reasons on the Jewish homecoming part of the story and not on the Jewish people's desert sojourn. Early Zionist thinkers such as Herzl, inspired by a fin-de-siècle nationalist fervor, searched for an authentic geographic space for the Jews to occupy. Herzl and his contemporaries realized that, as Michael Stanislawski explains in his critical examination of classic-Zionism, Zionism and the Fin-de-Siècle, that anti-Semitism did not dissipate as a result of European-Enlightenment thought. More crucially, it grew increasingly clear that the rising anti-Semitism in Europe at the end of the nineteenth century could not be attributed to obscure remnants from the Middle Ages. Instead, the anti-Semitism witnessed at the time proved a continuation of the former with renewed vigor. This time around, anti-Semites were armed with new scientific discourse presenting Jews' supposed racial inferiority ${ }^{9}$ (as well as other non-whites) (Stanislawski 9). Jews, Zionists decided, must find their own geo-political home ${ }^{10}$ away from Europe (Stanislawski 9).

Disturbingly, Theodore Herzl and some of his colleagues did not reject the discourse of racial determinism. They did not attempt to argue that Jews were not racially different and should therefore be accepted into European society as equals. On the contrary, they adopted the idea of a racially defined nationhood. Herzl went so far as to write in 1896 that anti-Semitism and specifically the fear of miscegenation, the adulteration of gentile blood with Jewish blood, was a form of "legitimate self-defense" on the part of European gentiles (Stanislwaski 14). In his famous novel Altneuland (Old-New-Land, 1902) Herzl describes a Palestinian Arab population that could not possibly object to Jewish immigration since these same Jews would bring with them European technological advancement. He imagines the Jews in Israel as a kind of aristocracy, reigning over the land with the Arabs taking a similar role to what he viewed as the East-Indians under British colonial rule. What becomes clear here is the way Herzl and his contemporary geo-political-Zionists used the rhetoric of European nation-building to inspire them into imagining a grand colonial presence with Jewish European culture ruling over the Arab population already living in Palestine. ${ }^{11}$

9 For an in depth scientific discussion of nineteenth century science, specifically hierarchy of racial worth, see Stephen Gould's The Mismeasure of Man (86, 87 and elsewhere in the book).

10 It is important to note here that they did not all view Palestine as the only possible location for a homeland. There was talk of Uganda, for example.

11 Interestingly, Jews were not the only ones to grow more interested in a geo-political solution for the Jewish race. For more, see Eitan Bar-Yosef's article, "Christian Zionism and Victorian Culture." 
Levinas, when he decried Zionism's ills, argued in essence that Zionism returned to the same, to its own self-enclosed system meaning that it needed to focus inwardly on Jewish pain only rather than being able to expand and see others around. Two thousand years of exile, followed by a promise to return to a home that can only be described as indigenous prompted an egocentric, ethnocentric paradigm. It is this ethnocentric, inward implosion that disturbed Levinas. Henry McDonald explains that there are "two very different but related moments of recognition" of others in Levinasian ethics. First, one recognizes the self, or the ego (McDonald ). In the first moment, the self, or ego, is constituted by its ways of knowing and understanding the world. The second moment occurs when the self encounters the physical presence of an other represented by the face or, as Levinas explains, "[t]here is, in the face, the supreme authority that commands... The face is the site of the word of God" (Levinas 2001: 215). Herzl relied on Enlightenment, on rationalist ideals, and at the same time expressed his ideas in terms of Jewish pain. For his and classic Zionist thought, there cannot be an encounter with the other. The very idea that Palestinian Arabs would unconditionally welcome European Jews returning to their native home reveals his inability to recognize and acknowledge the point of view of an other. Zionism, hence, remained in Herzl's rendering of it, in the first moment without the ability to move onto the second.

Shulamit Hareven, as Omer-Sherman points out, introduced a crucial examination of the metaphors the Zionist master-narrative utilizes. She poignantly argued that the homecoming story was founded on the morals and belligerent strategy of the Book of Joshua. She wrote in an essay from the 1990s that "there are people in this generation who have decided for some reason that the values of the Book of Joshua take precedence over the morals of Isaiah and the prophets" (Omer-Sherman 2006: 39). Omer-Sherman continues to explain that for her, the "grisly slaughters and conquests [described in Joshua] form the cynical palimpsest for present-day violence" (idem). He shifts her criticism with the help of Levinasian ethics and compares Joshua-like violence with Levinas' sense of the welcoming tent of the Abraham, exiled in the desert, always moving away from home toward otherness rather than always returning back to a sameness, which only assimilates, as war does, the other into the self. Where can we look to escape the Joshua-like conquest, the return to the same? The only space which challenges the centrality of the homeland, native ethos is the exile from Egypt and the consequent forty years in the Sinai desert.

Supplanting the centrality of Joshua's conquering with Abraham and his tent begins the movement away from the strategic master-narrative of classic Zionism to a tactics of encounter. Levinas writes in "Du sacré au saint": 
Above all Abraham is ... the one whose tent was open to the four winds...Abraham must have taken the three passers-by for three Bedouins, three nomads...three Arabs indeed!... Abraham's descendants are men to whom their ancestors bequeathed a difficult tradition of duties toward the other, which we have never finished fulfilling, an order from which we are never released, but where the duty takes on above all the form of obligation...Abraham's descendants are men of all nations: every man who is truly a man is probably a descendant of Abraham. (quoted in Omer-Sherman 12)

Levinas means that every person needs to strive for a kind of true humanity (I am here replacing "man" with humanity) by imagining oneself a descendant of Abraham. Each person can think of their obligation to the other in the same way as Abraham does. Levinas uses Abraham as a metaphor, connecting his nomadic existence with the need to constantly reach out to others. Such an existence is essentially tactical and local, and it eschews the grand strategies of war. After all, as Levinas points out in "Unforeseen History," "[w]e are reminded more than forty times in the Pentateuch that we must respect strangers," or as he summarizes, "the humanity of man begins with morals" (Levinas 1994: 119). Before Joshua could take over the leadership of the people and lead them violently into Canaan, the Jewish people encountered God and received the Torah in the desert. It is there that God dwelt closest to the people and where he bestowed upon them their ethical responsibility toward others. That, argues Levinas along with many other humanist Zionists (as we can perhaps call them), should be the main metaphor through which we think about modern day political dilemmas.

God's desert is a place where his presence only further stresses its potential disruption of the master-narrative. In "God and Philosophy," Levinas describes God's role in the meeting between the ego, the self, and the other. God, he writes, is further away from us than the stranger. If the stranger, the other, disrupts everything we know by thrusting upon us complete difference, then God introduces the idea of "absolute remoteness" (Levinas 1996: 141). The other, though disruptive to our egos via its complete strangeness, at least acts as an interlocutor, meaning that there is at least an encounter on some level. "Other with an alterity prior to the alterity of the other" Levinas writes of God and adds, "and different from every neighbor, transcendent to the point of absence, to the point of a possible confusion with the nothingness of the there is" (idem). God's presence-absence in the desert creates in this way an open space for ethical moments of encounter and disruptions by the other. God's very presence empties the land of all but his overriding expectations and leaves one facing that silent expectation. What better space to meet the infinity of the other and to begin rewriting the sameness of the Zionist master-narrative? The borders 
of the native homeland encase the egocentric, ethnocentric Zionist self. The desert exists as a kind of philosophical land, where indigenous longings coexist with possibilities of encountering others as people toward whom we have responsibilities. Clearly, the same encounter will prove much more complicated if not near-impossible inside what most Jewish-Israelis consider the heart of their homeland.

Another way to think about how Levinas' philosophy insists on responsible Zionism is by comparing it to Heidegger. In his seminal Being and Time (1927), Heidegger argues that the most important reference through which we learn of our existence is our awareness of our own mortality. We begin to act, insists Heidegger, when we face the possibility of our own death. Equate that with the indigenous wish for a place from which we begin and you have a space from which a person or a people feel they came and the place in which they want to face their death. Environment, understood as a point of origin, can be seen as a beginning and death as an end. Heidegger leads into that inner enclosing, a focus on our own sense of being against which Levinas warns. Zionism sought to connect people back to their homeland, so that suffering and death can have a meaning similar to other people living in what they consider their home: early Zionists wanted to live and die connected, rooted. In contrast, they felt that in Europe (as well as elsewhere) they had spent centuries uprooted and unwelcomed, in a hostile environment.

Martin Buber's I and Thou (1923) further expounds Levinas' response to Heidegger: Buber, a Zionist who pushed for Arab rights, described in I and Thou different encounters with others. The issue for Buber begins with a failure to see an "other" as such, as a person, a whole being. The idea of a whole being lies in acknowledging the person facing you deserves recognition. Too often, Buber warns, that relationship finds itself reduced to what he calls an "I-It" relationship. The difficulty of an "I-It" relationship is that it privileges our needs from others or others' needs from us over recognition of that person's humanity. It is thus impossible to meet a person devoid of utilitarian motives. In its purist form, an "I and Thou" relationship means encountering someone not as a means to an end but as a moment of complete recognition of the other's humanity, and basic existence. Levinas, similarly, argues that Heidegger stressed the "I will die one day" rather than looking outward towards others and shifting the focus to them. Levinas, takes an additional step, in a way, by insisting that the basis of our existence begins with the realization that "people around me will also die one day." He calls attention to those moments in our lives where the passing of a person caused us to look into ourselves and evaluate the meaning of our existence. 
What becomes of a philosophy of Being when we place others rather than ourselves in the middle of what drives us? Levinas posits that other people's whole humanity emerges, and the potential for concluding that other's existence matters while forsaking questions of its usefulness to us. Others exist, they matter, they are wholly human exactly to the same degree that I am. Now I will decide how to act in the world. For Levinas, the recognition of others follows recognition of our own existence. That is the second move McDonald discussed and it is there that ethical thought and action can begin. In an interview Levinas once explained the difference between Heidegger's es gibt (literally meaning "there is," meaning simply "being") as follows: the there is is unbearable in its indifference. Not an anguish but horror... When you were a child and someone tore you away from the adults and put you to bed a bit too early, [you were] isolated in the silence (Levinas 2001: 45). And the physical manifestation, the center locus of this feeling toward others is personified in the human face, for Levinas. It is there that supreme responsibility begins. As mentioned, the face is the supreme authority (Levinas 2001: 215). "From the very start you are not alone!" he proclaims (Levinas 2001: 50). While the ego, the individual, develops in a self-enclosed, self-referential mode (hence Heidegger's self enclosed anonymous es gibt), Levinas stresses that the other is always already there along with our supreme responsibility toward the other.

Levinas usefully introduces God into the relationship between beings. $\mathrm{He}$ introduces the concept of God as participating in the relationship between persons. Into the relationship of the I and Thou, the es gibt and the other, Levinas inserts God. Jewish religious tradition introduces a God who demands of us in the desert, again, more than forty times, consideration toward the other. Ignoring that responsibility, ignoring the face of the other, sinks one back into the self which will result in a horror. For Levinas, in other words, the "there is," the moment of facing Being is not about some anonymous anguish but rather about experiencing the worst kind of isolation from other people which results in feelings of horror. "[T] he true exit from [it] is in obligation, in the 'for the other,' which introduces a meaning into the nonsense," he continues (46). Obligation is a responsibility of encounter, not a strategy of domination -an idealized meeting of whole humans in Buber's sense and not a utilitarian object. Levinas calls this "ethics as first philosophy" (which is also the name of an article he published in 1984; see The Levinas Reader: 75-87). Instead of returning to the same as classic Zionism tends to do, Levinas argues that the responsibility toward the other acts as the very engine of our existence and enters even the master-narrative of return to our native homeland. When $\mathrm{Oz}$ prepares for us a scene where he comes "face to face" with an other, a representative of all those others, Arabs, mainly, against whom the Zionist ego pushes, he prepares 
a scene echoing loudly with Levinas' warning about ethical Jewish responsibility and with meeting fully, moving away from yourself to acknowledge an other's Being.

\section{Amos Oz's part in rethinking Zionism}

In the middle of $A$ Tale of Love and Darkness, Oz conceives a moment where he meets a perfect stranger, an other. A reader might gloss over the first five pages or so of Chapter 39. The encounter, however, deserves pause, close scrutiny, and recognition. $\mathrm{Oz}$ describes walking early one morning, as he does daily, to the edge of his street where the desert begins (at the time he lived on the edge of the desert, in the southeast city of Arad). He walks out to the edge of his Jewish Israeli town and stands facing the desert: "[e]very morning, a little before or a little after sunrise, I am in the habit of going out to discover what is new in the desert" (304). Specifically he yearns for "the full depths of the desert silence ${ }^{12}$ " and he finds it. In a stark and startling move, Oz shares this personal moment with the reader. Without warning, the reader is torn from the past-tense narrative of his family's almost fantastic tales in Europe and from Oz's recollections of his childhood in Jerusalem to be transplanted into Oz's present tense, his inner thoughts. The jarring shift, the choice to suddenly place the reader beside the writer rather than as the spectator of remembered events demands attention. Why shift so abruptly? The change in tense, setting, and discourse invites a close reading of this central passage.

The moment signals Oz's move from his far past (his family's history and his own childhood) to his more recent past, but it also signals a different kind of shift in his narrative. Up to that point in the book, he describes his life prior to 1947 and 1948, prior to Israeli independence, but now the book continues beyond the Independence War and into statehood. The short passage acts as a suture holding together the two parts of the autobiography, the pre and the post-independent Israel. Another possibility, of course, must be considered. Perhaps the passage acts rather to fissure the two parts, commenting on the

12 In Rhetoric and Death, Ronald Schleifer juxtaposes the work of Derrida, Eric Auerbach, and Kierkegard concerning God, prayer, and the silence inherent in Judaism in opposition to the visual richness of the Greek Homeric tradition (214-18), the brightness of the returning Ulysses in contrast to the dark inwardness of Judaism. In the desert Oz's participates in such inwardness - which has nothing to do with egoism - in a moment where the silence he experiences reflects the Jewish silence before God's Torah. His subsequent return home to write about his experience, further echoes the sense of Jewish responsibility to write what he (in this case) has heard. 
complex turn in the history of Zionism between the visions for a Jewish state and the later reality of that same state.

The passage begins with an encounter at the doorstep to the desert. A figure appears to him as he enjoys the morning breeze: "At the top of the hill facing me, suddenly there are three black goats and with them a human figure" (305). An other faces him, a figure which he cannot identify but imagines might be a Bedouin woman. She stands there motionless, "exactly on the horizon at the top of the hill facing me," just as the Levinasian other faces the self, as a physical presence (305). Almost as quickly as it appears, the figure disappears back into the desert, leaving $\mathrm{Oz}$ with the growing sounds of the morning coming from the desert-town behind him. At a moment when he searches for quiet in what he views as a kind of nothingness, a kind of immersion in the self, he meets a stranger. The figure enters his horizon and he cannot escape noticing it. It interrupted his self-involved silence and he finds himself pondering the figure, attempting in earnest to interpret it, unsuccessfully. He carries the encounter with him as he walks back into town to the sounds of the waking dogs, birds, and neighbors. "Back in my study," $\mathrm{Oz}$ continues, "with a mug of coffee in my hand and the morning newspaper spread out on the sofa, I stand at the window for another ten minutes. I hear about a seventeen-year-old Arab girl who has been seriously injured by a round of bullets after she tried to stab an Israeli soldier" (307). Between hearing about the Arab girl on the news and reaching home, $\mathrm{Oz}$ briefly speaks to a neighbor out watering his yard. The neighbor angrily announces that "[i]t seems one holocaust wasn't enough to teach us a lesson," referring to Israelis like $\mathrm{Oz}$ who hold conciliatory-political attitudes toward the Palestinians (307). It can be argued that the neighbor speaks from within the space of the enclosed self. For him, every political and military action taken by the Palestinians returns to the same interpretation of his world, the master narrative announcing Jews are targets everywhere, an understandable view since $\mathrm{Oz}$ discloses that the neighbor himself is a holocaust survivor.

$\mathrm{Oz}$ needed to venture to the edge of the desert to experience such a transforming moment with the other. $\mathrm{Oz}$ saw the stranger in the desert, perhaps even has experienced many such encounters there. Perhaps, the encounter never occurred outside of Oz's imagination. The description's meaning exists beyond its foundation in reality. Regardless whether it happened or not, the moment signals transcending facts of biography. The encounter lays philosophical ground for, first, the book as a whole, but second, his reaction to the news of the Palestinian girl. He resolves to write an article on her behalf in Yediot Aharonot, one of two major Israeli newspapers. In so doing, he moves away from his own pain as Jew feeling under attack in his native land towards the young girl and her existence as a suffering person. He demonstrates a resistance to 
pigeonholing her as "the enemy" whose acts cannot be understood or accounted for. The encounter in the desert draws in the philosophical background for the book. Oz does not condone the girl's actions but he simply refuses to have her humanity trampled upon by an "us" versus "them" Joshua-like militantness. Or, to add another of Levinas' metaphors, he is like Abraham who opens the flaps of his tent to welcome the pain of the other rather than reacting to the morning news events as well as to his neighbor's words by espousing the classic-Zionist Joshua-like "public line."

Using Abraham to exemplify welcoming strangers into your home proves especially telling since Abraham is also the patriarch with whom God established the covenant promising the land to the Jewish people:

I will establish my covenant as an everlasting covenant between me and you and your descendants after you for the generations to come, to be your God and the God of your descendants after you. The whole land of Canaan, where you now reside as a foreigner, I will give as an everlasting possession to you and your descendants after you; and I will be their God (Genesis 18:8, 9).

For the consequent two thousand years of exile, Jewish prayers have been inundated with the memory of Jerusalem, of the Second Temple that stood there, and the promise of God to Abraham. Jews all over the world pray facing Jerusalem and recite, among others, praises for Zion and Jerusalem including the words "Next year in Jerusalem." Oz, by entering the desert, steps outside of the space encapsulating that story as well as the story which includes, as its defining moment, Joshua's subsequent violent return, by stepping into the place where God dwelt closest to the Jewish people and the place where he gave them the Torah.

It is not difficult to understand Zionism's preoccupation with and stress on the Joshua, colonialist-like return to the land rather than with the desert ideal of exile and consideration toward the other. Certainly we, descendants of Eastern European Jews, can deeply understand and identify with the Zionist wish to find a political solution for Jews. We can identify with the wish to separate ourselves from the Gentiles or Goyim ${ }^{13}$ and from a constant threat of violence. I not only grew up in Israel, but I grew up as the granddaughter of a Holocaust survivor. My family was lost to Nazi violence on all sides. My paternal grandmother was the soul survivor of her family. She arrived in Israel as a young woman in 1945 after watching her family murdered before her eyes and surviving many other horrors. Both she and my paternal grandfather fought

13 The Hebrew word for Gentiles or non-Jews is Goyim. It appears in the book of Genesis to mean 'nation.' In modern usage, it means all other nations other than the Jews. 
in the Independence War (much like Shulamit Hareven). I am the daughter of a Jewish immigrant to Israel from Chile, a woman who left her family to find a new identity as Jew who can live safely inside a homeland in a way that only a people defined so deeply by their displacement and otherness can fully understand. In fact, the story $\mathrm{Oz}$ relates in his Aunt Haya's voice in A Tales of Love and Darkness, recollecting her life in Eastern Europe and her arrival in Israel, reminds me a great deal of my mother's stories, my grandmother's story, my great-grandmother's story. Listening to these stories underscores the grasp the Zionist, Joshua-like, mind-set had on many European Jews as well as Jews around the world.

Numerous pages in the memoir are dedicated to Oz's Aunt Haya, his mother's sister, and her first-person recollections. Aunt Haya recalls the extreme estrangement she felt in Europe, her supposed home: "There was a terror that we might, heaven forbid, make a bad impression on the Gentiles, and then they would be angry and do things to us too dreadful to think about" (190). Does it require any stretch of the imagination to sympathize with the fascination of the promise of homecoming especially following the Holocaust? The stories Aunt Haya and others tell of Europe are inundated with very real fear of violence. This was counteracted by a hope that there is a land where Jews can return to, a native, original place where they can be home: Aunt Haya writes, "I can't describe how all at once the joy rose up in my throat; suddenly all I wanted to do was shout and sing, This is mine!... I'd never experienced such a strong feeling before in my life, of belonging, of ownership" (197). She does not mean "mine" as in "I am now here and shall take it" in the colonial sense. She speaks as a lost descendant coming to inherit an ancient homestead. These kinds of stories took hold, received priority and turned into the national ethos. They turned into the quintessential Zionist master-narrative.

Not that the much dreamt of homecoming proved easy. Still, many immigrants needed desperately to believe in the possibility of a new life as Aunt Haya explains:

Naturally we knew how hard it was in the Land: we knew it was very hot, a wilderness and we knew there was unemployment, and we knew there were poor Arabs in villages... and that maybe the Arabs were just being stirred up to hate us, like the simple people in Poland, but surely we'd be able to explain to them and persuade them that our return to the Land represented only a blessing for them, economically, medically, culturally, in every way. (192)

What is crucial to understand about the position Oz takes in light of the history he recounts is that he is not only reacting against some faceless European Zionists but he is reconceptualizing what his own family espoused. Many of us struggling today with issues of justice as they relate to the grand-strategic 
solutions of classic Zionism understand that we are reacting to these stories emerging from our families. These are not stories that rely on binaries of pain in that they do not know how to consider the Arab other.

It is important to note that many Jews currently living outside of Israel struggle with their place in the world in light of Israel. Zionism did not solve for many Jews around the world the question of where they belong nor does it solve for them what Israel and Israelis mean for them. Caren Aviv and David Shneer in New Jews: The End of the Jewish Diaspora (2005) assert that the idea of a rebirth in an original home does not relate to them. The writers, a former Israeli Jew and an American Jew, complain about what they call elitist attitudes taken by Israeli Jews over "Diaspora" Jews and insist that New York is as much home for Jews as Tel Aviv. Jews, like other groups, react differently. For many, however, Israel is understood to be at the very least a spiritual home.

Omer-Sherman's personal experience with the Zionist ethos proves important to this conversation because it offers a contemporary example in addition to Aunt Haya's slightly dated one (she immigrated into Israel before the Second World War). Some find themselves questioning the classic-Zionist master-narrative. Omer-Sherman's understanding was crystallized when he traveled to Israel as a young American Jewish man. He describes in the introduction to his first two books, Diaspora and Zionism (2002) and Israel in Exile (2006), his personal experience in Israel. As a young man he joined the Israel Defense Force (IDF) and then found his way to the Arava (in southeast Israel) where he joined others in establishing a kibbutz. He writes, "I milked cows, harvested dates, and led Jewish teenagers from around the world on desert treks"14 (Omer-Sherman2002: 12). The life he led gave him "a giddy sense" that he could "unravel" himself "from the weight of all that historical trauma," referring to the trauma of two millennia of persecution in exile (Omer-Sherman 2006: xi). He imagined he "would bypass history and establish a new identity in the pure expanses of stone and sand" (idem).

At first he felt that he "somehow echoed that early Zionist generation's fervent quest for an 'authentic', indigenous core that would demonstrate one's

14 See Space and Place in Contemporary Israeli Discourse and Experience, edited by Eyal Ben-Ari and Yoram Bilu for more. Particularly, see Orit Ben-David's "Tiyul (Hike) as an Act of Consecration of Space" where she discusses the ways that the mandatory school-organized hikes as well as weekend family hikes act as "a declaration of territorial claim, and a consecration of space..." (130). She adds, "By the act of hiking people strengthen their feeling of legitimacy of their claim to the land" (142). See also "Remaking Place" by Tamar Katriel and her discussion of historical settlement museums in Israel which embody master-narratives "which in various ways articulate the central story of Zionist fulfillment" (149). 
essential at-homeness in the exotic landscape as much as the Bedouin of whom one caught occasional glimpses, no matter where one came from" (idem). The Zionist promise seemed to come to fruition for him. However, after a long period of uncritically finding himself "caught up in the essential justness of the Jewish national cause," the sense of disillusionment began to enter the supposed picture-perfect world. Once he did begin critically examining the Zionist project, he realized the full complexity of the ethical situation at hand. On the one hand, in Diaspora and Zionism, he stresses that the "Palestinians and Israelis, each rightly persuaded of their own victimhood, are suffering terribly from the violent consequences of traversing Exile and Home" (Omer-Sherman 2002: 14). On the other hand, Omer-Sherman discovered that the Zionist master-narrative, mainly that of reoccupying Israel aggressively, conflicted deeply with his own sense of the ethical. His second book, Israel in Exile, came out of those ethical concerns and is indicative of a new important critical voice searching for an ethical alternative to the master narrative.

" $[\mathrm{T}]$ here is a distinct schism between the founding ideals of the parents and their successors, who find themselves weary of what appears to be an endless state of war and its high costs of survival," Omer-Sherman writes (Omer-Sherman 2006: 62). For Oz, as well as for other writers, as Omer-Sherman points out in Israel in Exile, the desert offers an important locale for an alternative voice. "Early in his career," Omer-Sherman writes, "Oz discovered that the desert offered a unique environment for posing critical questions about the individual and society" (idem). The memoir should be read as one of a man who proclaims that he, at least, is willing to live in a constant state of disruption of his world-view. Moreover, he goes out into the desert looking for a renewal of his discomfort. One can almost see him venturing into the desert in a self-defeating, painful reiteration of the final meaning of the silence he seeks. Though he cannot offer a solution to the war, he can insist on his responsibility toward justice for the neighbor even if it means a "mere" article in the newspaper. His voice along with those of other intellectuals and authors such as Shulamit Hareven and others are voices that remind us that though we may not be able to stop the war completely at the moment, it is our constant responsibility, and has been from the very beginning, to demand justice. It is therefore not a coincidence that Levinas' ideas are growing in centrality inside Jewish Studies. A growing number of scholars turn to Levinas' work to assist them in rethinking issues of nationhood, wars, and ethical responsibility toward the other, especially in a post-Holocaust context.

One last crucial question remains to be voiced. Will this alternative narrative that the desert and that Levinas offer promise a happy end to the powerfully tragic story unfolding in the Promised Land? Will stressing the other lead to 
a just solution for both sides, the Israeli and the Palestinian? Levinas, at least, promises nothing. Placing the other before oneself is first and foremost an ethical imperative beyond any promises of happiness. Levinas reiterates that facing the other will sooner result in an agitation or a disruption of one's own ego, one's sense of self, than in a utopian happy ending. The process is not pleasant nor should it be. He writes in "Ethics as First Philosophy," that "[ $t]$ he other as face... the alterity of the infinite who commands me and elects me for its service, represents the ethical agitation of being" (Levinas 2001: 218). There are, therefore, no promises of a happy end because "the first and last manifestation of God would be to be without promises" (idem). Amos Oz's memoir and the moment he describes needs to be read with this point in mind.

$\mathrm{Oz}$ echoes Levinasian ethics when he describes not a solution but a new language for the conversation about the war. His understanding of the tragic situation reflects a sense of responsibility regardless of happy-end considerations. There is no self-serving moment here because, there is no language - no strategy - pertaining to winning a war. Again as Levinas explains, "[ $t$ ]he Jew begins with obligation. And the happy end is uncertain” (Levinas' stress, 2001: 267). Oz writes:

My definition of a tragedy is a clash between right and right. And in this respect, the Israeli-Palestinian conflict has been a tragedy, a clash between one very powerful, very convincing, very painful claim over this land and another no less powerful, no less convincing claim. Now such a clash between right claims can be resolved in one of two manners. There's the Shakespearean tradition of resolving a tragedy with the stage hewed with dead bodies... But there is the Chekhov tradition. In the conclusion of the tragedy by Chekhov, everyone is disappointed, disillusioned, embittered, heartbroken, but alive. (quoted in Israel in Exile 2006: 65)

Perhaps this is what justice looks like eventually in a Levinasian world. Perhaps responsibility for the other will result in disruption of the utopian visions of the same and in disappointment. There are no promises. But there are no final solutions either, and perhaps we will at least know that we placed ethics first and primarily asked questions regarding justice. Then maybe, just maybe, we will all at least live to see a resolution, without promises.

\section{Works Cited}

CARYN, Aviv and SHNEER, David. New Jews: the End of the Jewish Diaspora. New York: New York University Press, 2005. 
BAR-YOSEF, Eitan. "Christian Zionism and Victorian Culture" Israel Studies 8 (2003). 18-44.

BEN-DAVID, Orit. "Tiyul (Hike) as an Act of Consecration of Space. Grasping Land, Space and Place in Contemporary Israeli Discourse and Experience. Ed. Eyal Ben-Ari and Yoram Bilu. New York: State University of NY Press, 1997. 129-145.

BUBER, Martin. I and Thou. A New Translation, with a prologue and notes. 1923. Trans. Walter Kaufmann. New York: Simon and Schuster, 1996.

DERRIDA, Jacques. Adieu to Emmanuel Levinas. Stanford: Stanford University Press. 1999.

Encyclopedia Judaica. "Shulamit Hareven." Jewish Virtual Library. American Israeli Cooperative Enterprise, 2008. Web. June 28, 2016.

GOULD, Stephen J. The Mismeasure of Man. New York: W.W. Norton \& Co., 1996.

GUREVITCH, Zali. "The Double Site of Israel." Grasping Land, Space and Place in Contemporary Israeli Discourse and Experience. Ed. Eyal Ben-Ari and Yoram Bilu. New York: State University of NY Press, 1997. 203-216.

HEIDEGGER, Martin. Being and Time: A Translation of Sein und Zeit. Trans. Joan Stambaugh. New York: State University of New York Press, 1996.

HERTZBERG, Arthur. Introduction. The Zionist Idea, A Historical Analysis and Reader. Ed. Arthur Hertzberg. Philadelphia: The Jewish Publication Society, 1997.

HOWE, Irving. World of Our Fathers. New York: Galahad Book, 1976.

Israel Ministry of Foreign Affairs. "Minority Communities in Israel: Background and Overview." Jewish Virtual Library. American Israeli Cooperative Enterprise, February 2016. Web. June 28, 2016.

KATRIEL, Tamar. "Remaking Place, Cultural Production in Israeli Pioneer Settlement Museums." Grasping Land, Space and Place in Contemporary Israeli Discourse and Experience. Ed. Eyal Ben-Ari and Yoram Bilu. New York: State University of NY Press, 1997. 147-175.

LAQUEUR, Walter. A History of Zionism: From the French Revolution to the Establishment of Israel. New York: Schocken books, 2003.

LEVINAS, Emmanuel. "Secularism and the Thought of Israel." Unforeseen History. Trans. Nidra Poller. Urbana-Champaign: University of Illinois Press, 1994. 113-124.

LEVINAS, Emmanuel. "Difficult Freedom." The Levinas Reader. Ed. Sean Hand. Oxford: Blackwell, 1998. 249-266.

LEVINAS, Emmanuel. "God and Philosophy." Basic Philosophical Writings. Ed. Adriaan T. Peperzak. Bloomington: Indiana University Press, 1996.129-148 
LEVINAS, Emmanuel. "Meaning and Sense". Basic Philosophical Writings. Ed. Adriaan T. Peperzak. Bloomington: Indiana University Press, 1996. 33-64.

LEVINAS, Emmanuel. "Ideology and Idealism." The Levinas Reader. Ed. Sean Hand. Oxford: Blackwell, 1998. 235-248.

LEVINAS, Emmanuel. "Interview with François Poirie." "Ethics as First Philosophy." Is It Righteous To Be? Interviews with Emmanuel Levinas. Ed. Jill Robbins. Stanford: Stanford University Press, 2001. 13-83.

LEVINAS, Emmanuel. "The Proximity of the Other." "Ethics as First Philosophy." Is It Righteous To Be? Interviews with Emmanuel Levinas. Ed. Jill Robbins. Stanford: Stanford University Press, 2001. 211-218.

MCDONALD, Henry. "Ethics of Tragedy," unpublished essay.

Omer-Sherman, Ranen. Diaspora and Zionism in Jewish American Literature, Lazarus, Syrkin, Reznikoff, Roth. Hanover: Brandeis University Press, 2002.

OMER-SHERMAN, Ranen. Israel in Exile, Jewish Writing and the Desert. Urbana: University of Illinois Press, 2006.

OZ, Amos. A Tale of Love and Darkness. Trans. Nicholas de Lange. Orlando: Harcourt, 2004.

REMNICK, David. "The Spirit Level: Amos Oz writes the story of Israel." The New Yorker., 8 November, 2008. Web. July 17, 2016.

STANISLAWSKI, Michael. Zionism and the Fin de Siecle. Berkeley: University of California Press, 2001.

SCHLEIFER, Ronald. Rhetoric and Death: The Language of Modernism and Postmodern Discourse Theory. Urbana and Chicago: University of Illinois Press, 1990.

\begin{abstract}
This essay describes Amos Oz's encounter in the desert with a Bedouin woman in his Tale of Love and Darkness (2004). The encounter transforms the politics of the land by reminding readers that a Jewish home is also homelessness and the desert is a nomadic space that represents both home and exile. The desert allows $\mathrm{Oz}$ to transform a Joshua-like conquest story to a place where Levinas' responsibility toward the ger, the stranger, presides. The term "binary of pain" acts to highlight Zionism's potential, inherent in its Jewish roots, for encountering the Palestinian rather than enacting the language of war. I argue that Levinasian ethics, which stress responsibility for the Other, offer a tactics of encounter, creating a space for smaller gestures which can beget resolutions.
\end{abstract}

Keywords: Amos Oz, home, exile, Levinas, Jewish studies.

Orit Rabkin was born and raised in Israel. She received her Bachelor's in English at the University of Haifa in Israel and her MA and PhD from the University of Oklahoma. She began working on women writers of the nineteenth century and quickly focused on Emma Lazarus, whose famous poem, "The New Colossus" adorns the base of the Statue of Liberty. Rabkin's primary research interests currently are in the field of Jewish-American literature. Specifically, she is interested in the ways Jewish culture intersects with identities such as Israeli and American. She has published on the first Jewish-woman Judge elected to the National Labor Relations Board in the United States, Anne Schelzinger. She is currently working on a book on Emma Lazarus. She teaches American literature and English at Ben Gurion University of the Negev in the south of Israel, in the desert. 
Résumé: Cet article décrit la rencontre dont $\mathrm{Amos} \mathrm{Oz}$ fait l'expérience dans le désert avec une femme bédouine, et dont il rend compte dans A Tale of Love and Darkness (2004). La rencontre transforme la politique de la terre en rappelant aux lecteurs qu'un foyer juif est aussi dans le déracinement et que le désert est un espace nomade qui représente à la fois le foyer et l'exil. Le désert permet à $\mathrm{Oz}$ de transformer un territoire conquis en un espace dans lequel prévaut la notion levinasienne de responsabilité envers l'étranger. L'expression « binaire de la douleur » met en valeur le potentiel de rencontre avec l'Autre palestinien, inhérent dans les racines juives du Sionisme, au lieu de reproduire le langage de la guerre. L'éthique de Levinas, qui met en avant la responsabilité vis-à-vis de l'Autre, fournit une stratégie de la rencontre, en créant un espace pour de petits gestes qui engendrent des résolutions.

Mots-clefs : désert, sionisme, Amos $\mathrm{Oz}$, patrie, exil, Emmanuel Levinas, études juives.

Orit Rabkin est née et a grandi en Israël. Elle a obtenu une licence de l'Université de Haifa en Israël, ainsi qu'un master et un doctorat de l'Université d'Oklahoma. Elle commença à étudier les écrivaines du XIX siècle et s'est rapidement focalisé sur Emma Lazarus, dont le célèbre poème "Le Nouveau Colosse » orne le piédestal de la statue de la liberté. Les principaux intérêts de recherche de Rabkin concernent la littérature juive américaine. En particulier, elle s'intéresse aux façons dont la culture juive recoupe les identités israëlienne et américaine. Elle a publié sur Anne Schelzinger, la première juge juive américaine élue au National Labor Relations Board. Elle travaille actuellement à la rédaction d'un ouvrage sur Emma Lazarus. Elle enseigne la littérature américaine et l'anglais à l'université Ben Gourion, dans le désert du Neguev, dans le sud d'Israël. 